\title{
THE MEDITERRANEAN DIET IN THE PREVENTION OF CARDIOVASCULAR AND NERVOUS SYSTEM DISEASES - THE ASSESSMENT OF NUTRITIONAL KNOWLEDGE
}

DOI: 10.36740/WLek202007125

\author{
Kamila Wachuła, Joanna Furman, Beata Łabuz-Roszak \\ DEPARTMENT OF BASIC MEDICAL SCIENCES, FACULTY OF HEALTH SCIENCES IN BYTOM, MEDICAL UNIVERSITY OF SILESIA IN KATOWICE, \\ BYTOM, POLAND
}

\begin{abstract}
Introduction: Following a Mediterranean diet significantly reduces the risk of cardiovascular and neurodegenerative diseases.

The aim of the study was to assess nutritional knowledge among adult residents of the Silesian Province on the Mediterranean diet in the prevention of cardiovascular and nervous system diseases.

Material and methods: The study was conducted using an anonymous self-made questionnaire. 190 adults from the Silesian Province participated in the study.

Results: The respondents had a good or sufficient level of knowledge on the Mediterranean diet. Respondents as the benefits of using the Mediterranean diet more often indicated a reduction in the risk of cardiovascular diseases than prevention of nervous system diseases.

Conclusions: The inhabitants of Silesian Province have a fairly good level of knowledge on the preventive use of the Mediterranean diet. Public knowledge on the prevention of cardiovascular diseases, as well as knowledge on the principles of the Mediterranean diet, and on the benefits of its use, can reduce the incidence of cardiovascular and nervous system diseases.
\end{abstract}

KEY WORDS: Mediterranean diet, prevention, cardiovascular diseases, nervous system diseases

Wiad Lek. 2020;73(7):1448-1453

\section{INTRODUCTION}

A proper diet is one of the very important factors in the prevention of diseases of the nervous and cardiovascular systems [1-7]. The Mediterranean diet is often recommended. The traditional Mediterranean diet is mainly based on the consumption of fresh vegetables and fruits, whole grain cereals, vegetable oils, mainly olive oil, fish and legume seeds. Restrictions include red meat, dairy products, saturated fatty acids, and alcohol [8].

Following a Mediterranean diet can significantly reduce the risk of cardiovascular disease, including stroke and heart attack [7]. The beneficial effects of the Mediterranean diet are probably related to the action of the nutrients it contains, which may have an effect on lowering blood pressure, lowering lipids, improving metabolism and preventing inflammation in the body [7-11].

It was also shown that following a Mediterranean diet may have a beneficial effect on reducing the risk of neurodegenerative diseases such as Alzheimer's disease or Parkinson's disease $[6,12]$. The following nutrients supplied to the body during the diet are responsible for beneficial effects on the nervous system: antioxidants (vitamin C, vitamin E), mono- and polyunsaturated fatty acids, coenzyme Q10, glutathione, flavonoids, curcumin, and caffeine [2].

\section{THE AIM}

The aim of the study was to assess nutritional knowledge among adult residents of the Silesian Province on the use of the Mediterranean diet in the prevention of cardiovascular and nervous system diseases.

\section{MATERIAL AND METHODS}

190 inhabitants of the Silesian Province, 125 women $(65.8 \%)$ and 65 men (34.0\%) participated in the study.

The research tool was the author's proprietary anonymous questionnaire, consisting of single and multiple choice questions and open questions. One point was given for each correct answer, and 0 - for every incorrect answer and "I don't know" answer. The maximum number of points was 26. In order to assess the knowledge of the respondents, the following point scale was established: $0-7$ points - unsatisfactory (E); 8 - 13 - admitting (D); $14-18$ - satisfactory (C); $19-23-\operatorname{good}(\mathrm{B}) ;$ and $24-26$ - very $\operatorname{good}(\mathrm{A})$.

\section{RESULTS}

The largest part of the study group were people aged 18 - $29(\mathrm{n}=145 ; 76.3 \%) .148$ people $(77.9 \%)$ lived in the 
Table 1. General knowledge on the Mediterranean diet.

\begin{tabular}{|c|c|c|}
\hline Question & Possible answers & n [\%] \\
\hline \multirow{4}{*}{ Definition of the Mediterranean diet } & Nutritional habits of people living in the Mediterranean* & $114[60.0 \%]$ \\
\hline & Type of slimming diet & $13[6.8 \%]$ \\
\hline & Diet based on the complete elimination of meat from the diet & $13[6.8 \%]$ \\
\hline & Diet based mainly on eating vegetables and fruits & 50 [26.4\%] \\
\hline \multirow{4}{*}{ Benefits of using the diet } & Reduction of cardiovascular risk * & $175[92.1 \%]$ \\
\hline & Reduction of the risk of cancer* & 84 [44.2\%] \\
\hline & Prevention of peptic ulcer disease & 28 [14.7\%] \\
\hline & Slowing down the aging process of the nervous system * & 79 [41.6\%] \\
\hline \multirow{8}{*}{$\begin{array}{l}\text { Diseases which risk can be reduced by } \\
\text { following a Mediterranean diet }\end{array}$} & Myocardial infarction* & $171[90.0 \%]$ \\
\hline & Ischemic heart disease ${ }^{*}$ & $142[74.7 \%]$ \\
\hline & Stroke ${ }^{*}$ & 94 [49.5\%] \\
\hline & Celiac disease & $2[1.1 \%]$ \\
\hline & Alzheimer's disease ${ }^{*}$ & $70[36.8 \%]$ \\
\hline & Cancer $^{*}$ & 82 [43.2\%] \\
\hline & Osteoporosis* & $29[15.3 \%]$ \\
\hline & Peptic ulcer disease & 34 [17.9\%] \\
\hline \multirow{3}{*}{$\begin{array}{l}\text { Reducing the risk of developing } \\
\text { cardiovascular disease }\end{array}$} & Yes $^{*}$ & $161[84.7 \%]$ \\
\hline & No & $3[1.6 \%]$ \\
\hline & I don't know & $26[13.7 \%]$ \\
\hline \multirow{3}{*}{ Influence on life length } & Yes $^{*}$ & $153[80.5 \%]$ \\
\hline & No & $5[2.6 \%]$ \\
\hline & I don't know & 32 [16.9\%] \\
\hline \multirow{3}{*}{ Use in obesity prevention } & Yes $^{*}$ & $140[73.7 \%]$ \\
\hline & No & 6 [3.3\%] \\
\hline & I don't know & $44[23.2 \%]$ \\
\hline \multirow{3}{*}{$\begin{array}{c}\text { Decrease the risk of neurodegenerative } \\
\text { diseases }\end{array}$} & Yes $^{*}$ & 95 [50.0\%] \\
\hline & No & $15[7.9 \%]$ \\
\hline & I don't know & 80 [42.1\%] \\
\hline \multirow{4}{*}{ Effect on total serum cholesterol level } & Decrease the level $^{*}$ & $138[72.6 \%]$ \\
\hline & Increase the level & $1[0.5 \%]$ \\
\hline & No influence on the level & 9 [4.8\%] \\
\hline & I don't know & $42[22.1 \%]$ \\
\hline
\end{tabular}

* correct answers

city, while 42 people $(22.1 \%)$ lived in a rural area. The majority of respondents $(n=118 ; 62.11 \%)$ had secondary education.

The vast majority of respondents ( $n=178 ; 93.7 \%)$ did not report diagnosed cardiovascular and nervous system diseases. Other respondents indicated hypertension, varicose veins of the lower extremities and atrial fibrillation. In families of respondents the following diseases were present: hypertension $(\mathrm{n}=96 ; 50.5 \%)$, prior myocardial infarction $(\mathrm{n}=78 ; 41.1 \%)$, stroke $(\mathrm{n}=45 ; 23.7 \%)$, ischemic heart disease $(\mathrm{n}=20 ; 10.5 \%)$, dementia $(n=30 ; 15.8 \%)$, Parkinson's disease $(n=13$; $6.8 \%)$, venous thrombosis $(\mathrm{n}=30 ; 15.8 \%)$ and atherosclerosis $(\mathrm{n}=47 ; 24.7 \%)$.
$60 \%(n=114)$ of the respondents knew the correct definition of the Mediterranean diet. The most common benefits of the Mediterranean diet were associated with a reduced risk of cardiovascular diseases. To a lesser extent, the respondents believed that the Mediterranean diet would have an impact on reducing the risk of developing cancer or nervous system diseases. The vast majority of respondents ( $n=153 ; 80.5 \%$ ) thought that life expectancy was to some extent dependent on the use of the Mediterranean diet. About $70 \%$ of respondents $(n=140)$ associated the Mediterranean diet with obesity prevention. In addition, approximately $70 \%(n=138)$ were of the opinion that total serum cholesterol levels would decrease due to the Mediterranean diet (Table 1). 


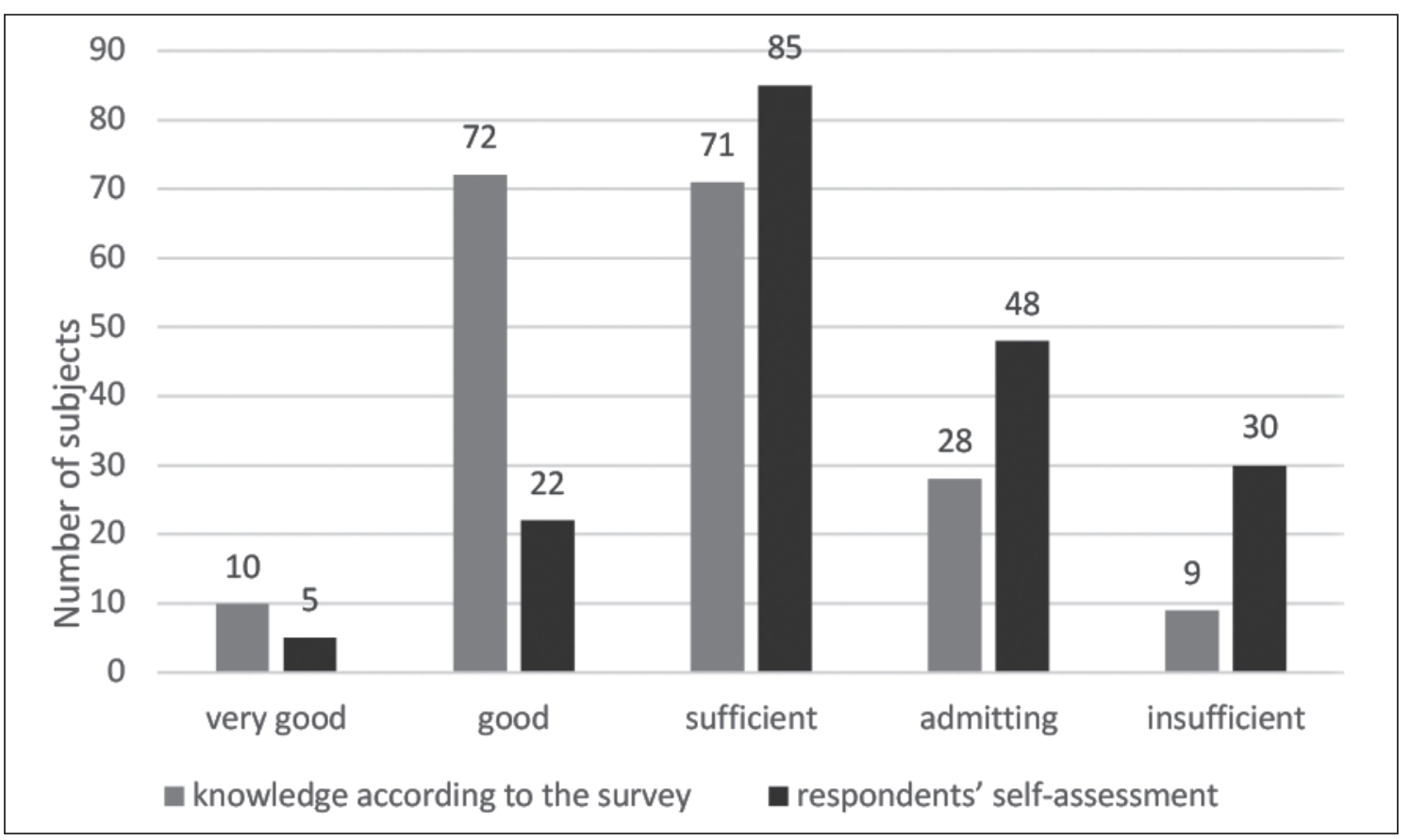

Fig. 1. The level of respondents knowledge according to survey results and self-assessment - the comparison.

The main source of fat in the Mediterranean diet is olive oil. Almost $90 \%(n=170)$ of the respondents had correct knowledge on this subject. About $60 \%(n=113)$ found that the recommended amount of vegetables and fruits in the Mediterranean diet is 4-5 servings. Most respondents knew that fish consumption should be at least twice a week ( $\mathrm{n}$ $=151 ; 79.5 \%)$. In the question about red wine, more than half of the respondents $(n=108 ; 56.8 \%)$ chose the correct amount of alcohol. Fish as the product that should be most often found in the Mediterranean diet was indicated by 173 respondents $(91.1 \%)$. In the question about fatty acids in which the Mediterranean diet is rich, half of the respondents chose all three correct answers. Most often, the Mediterranean diet was associated with omega-3 $(\mathrm{n}=$ $160 ; 84.2 \%)$ and / or omega- $6(\mathrm{n}=89 ; 46.8 \%)$ fatty acids. Most of the respondents $(\mathrm{n}=143 ; 75.3 \%)$ indicated vegetable protein as the main source of protein. Most often, the respondents $(\mathrm{n}=165 ; 86.8 \%)$ gave the correct answer that dark bread should predominate in the Mediterranean diet (Table 2).

The vast majority of respondents $(\mathrm{n}=165 ; 86.8 \%)$ were aware that in addition to the Mediterranean diet, physical activity also played an important role in the prevention of cardiovascular and nervous system diseases. 25 people (13.2\%) believed that physical activity was not significant or did not have knowledge about it.

The results of the survey indicate that the respondents most often presented a good or sufficient level of knowledge. A comparison of the results obtained with the results of the respondents' self-assessment showed that the self-assessment of the respondents who obtained a very good or good grade was lower than their actual results, while the self-assessment of people whose knowledge was assessed as sufficient, admitting or insufficient was higher. (Fig. 1).

\section{DISCUSSION}

In recent years an increase in the incidence of cardiovascular and nervous system diseases has been observed. In the management of these diseases, prevention is extremely important, among others, by changing incorrect eating habits and adequate physical activity. In the prevention of many diseases of the nervous system, as well as cardiovascular system, the Mediterranean diet has proven effective, which is considered one of the healthiest diets in the world [3].

In this study, the majority of respondents (84.7\%) knew that the Mediterranean diet reduced the risk of developing cardiovascular diseases. These results were similar to those reported in the available literature. In 2017, a survey was conducted among 200 students of nursing, medicine, emergency medicine and obstetrics studying at the Medical University of Lublin. 74.5\% of students were of the opinion that "the Mediterranean diet consisting of eating whole grains, unprocessed meat, seeds, nuts, vegetables, unsaturated fats" is a diet recommended for the prevention of cardiovascular diseases. However, 39\% of respondents incorrectly indicated that a diet high in polyunsaturated fatty acids is a risk factor for coronary heart disease. The highest level of knowledge about the risk factors of ischemic heart disease was presented by midwifery students, and the lowest - by emergency medical students [14].

The vast majority of respondents were also aware that physical activity plays an important role in the prevention of cardiovascular and nervous system diseases. Similar conclusions were made in the study of Krzyżanowska et al. In 2017, in which $76.5 \%$ of respondents showed a high level of knowledge about the impact of physical activity on the risk of cardiovascular diseases [14]. Also, in a study among students of the Medical University of Wrocław, it was shown that $98.9 \%$ claimed that physical activity was important in the prevention of cardiovascular diseases [15]. 
Table 2. Nutritional recommendations in the Mediterranean diet

\begin{tabular}{|c|c|c|}
\hline Question & Possible answers & n [\%] \\
\hline \multirow{4}{*}{ Basic source of fat } & Olive oil $^{*}$ & 170 [89.5\%] \\
\hline & Butter & $1[0.5 \%]$ \\
\hline & Lard & $4[2.1 \%]$ \\
\hline & Coconut oil & $15[7.9 \%]$ \\
\hline \multirow{4}{*}{ Number of servings of vegetables and fruits } & Less than 2 & $2[1.0 \%]$ \\
\hline & $2-3$ & 57 [30.0\%] \\
\hline & $4-5^{*}$ & $113[59.5 \%]$ \\
\hline & 6 or more & 18 [9.5\%] \\
\hline \multirow{4}{*}{ Frequency of fish consumption } & Once a week & 38 [20.0\%] \\
\hline & At least 2 times per week ${ }^{*}$ & $151[79.5 \%]$ \\
\hline & Once a month & $0[0.0 \%]$ \\
\hline & Less than once a month & $1[0.5 \%]$ \\
\hline \multirow{4}{*}{ Amount of red wine allowed } & At least one glass per day & $41[21.6 \%]$ \\
\hline & $\begin{array}{l}\text { Maximum one glass a day for women } \\
\text { and } 2 \text { glasses a day for men }{ }^{*}\end{array}$ & $108[56.8 \%]$ \\
\hline & Maximum one glass a month & 22 [11.6\%] \\
\hline & Prohibited in the Mediterranean diet & 19 [10.0\%] \\
\hline \multirow{4}{*}{ Food product that should be consumed most often } & Red meat & 3 [1.5\%] \\
\hline & Fish $^{*}$ & $173[91.1 \%]$ \\
\hline & White meat & 7 [3.7\%] \\
\hline & Eggs & 7 [3.7\%] \\
\hline \multirow{4}{*}{ Fatty acids in which the Mediterranean diet is rich } & Monounsaturated fatty acids* & $48[25.3 \%]$ \\
\hline & Saturated fatty acids & 28 [14.7\%] \\
\hline & Fatty acids omega- $3^{*}$ & $160[84.2 \%]$ \\
\hline & Fatty acids omega- $6^{*}$ & 89 [46.8\%] \\
\hline \multirow{2}{*}{ Protein predominating in the Mediterranean diet } & Vegetable Protein ${ }^{*}$ & $143[75.3 \%]$ \\
\hline & Animal Protein & $47[24.7 \%]$ \\
\hline \multirow{2}{*}{ Type of bread } & Light & 25 [13.2\%] \\
\hline & Dark $^{*}$ & $165[86.8 \%]$ \\
\hline
\end{tabular}

\section{* Correct answer}

The subjects were also asked about the role of the Mediterranean diet in maintaining a healthy body weight. Most of the respondents knew that this diet could be used to prevent obesity. This diet turns out to be effective not only in the prevention of obesity, but also in its treatment. In the study of Rajewski et al. concerning obese women, a diet based on the principles of the Mediterranean diet was used and appropriate physical activity was performed. The results of this study confirmed the effectiveness of this diet and adequate physical activity in the treatment of obesity [16]. Also, in the study of Schlegel-Zawadzka et al. comparing the diet of adult residents of Poland and Greece, it was shown that obesity was much less common in people using the recommendations of the Mediterranean diet [17].

The author's survey also asked about the amount of red wine allowed during the day according to the recommenda- tions of the Mediterranean diet. The correct answer, which was "a maximum of one glass a day for women and two glasses a day for men", was given by more than half of the respondents. Similar results were obtained by Krzyżanowska et al. The majority of students (59.0\%) answered correctly that in cardiovascular diseases the maximum permissible amount of ethyl alcohol is 20-30 g for men and 10-20 g for women [14].

During 25 years of observation of the diet of randomly selected populations, a relationship was found between saturated fatty acid intake and mortality due to coronary heart disease. The inhabitants of Japan, whose diet contained the least saturated fatty acids, were also characterized by the lowest mortality rate due to coronary heart disease. This rate was about six times lower compared to the population of Eastern Finland where the consumption of saturated fatty acids was the highest [18]. 
In the author's study, a percentage of $25.3 \%$ of respondents believed that the Mediterranean diet was rich in monounsaturated fatty acids. Especially monounsaturated fatty acids were used in the prevention of cardiovascular diseases $[19,20]$. At the same time, it was confirmed that the consumption of excessive amounts of saturated fatty acids was synonymous with an increased risk of coronary heart disease [20].

In this study, the knowledge of the inhabitants of the Silesian Province was mostly classified at a good or sufficient level. The respondents had information on the type of fat used in the Mediterranean diet, the frequency of consumption of fish, vegetables and fruit, and the type of bread recommended. However, knowledge does not always translate into its practical application. In one of the available studies, conducted among 151 students of medicine and dietetics (aged 21 to 23) of the Medical University of Warsaw, the correctness of their diet with the principles of the Mediterranean diet was assessed. The diet in this group was assessed by the method of eating food frequency in the 3 months preceding the study. Then, data averaged over the week period was calculated using the value of the Mediterranean diet compliance index. It is the ratio of energy that comes from products characteristic of the Mediterranean diet to energy from other consumed products. This indicator was adapted to Polish conditions. Researchers drew the basic conclusion that the diet of the studied group of students was significantly different from the principles of the Mediterranean diet. Despite the declaration of the Mediterranean diet by several medical students, the calculated index was higher than the average of the other students, however it was much lower than the index determined for the Mediterranean diet. Also, the amount of food consumed in this group was not fully in line with the principles of the Mediterranean diet. Therefore, all students should change their current diet model by increasing the consumption of fruit, pulses and vegetable fats, and reduce the consumption of animal fats [21].

The Mediterranean diet finds its application in the prevention and treatment of cardiovascular diseases. In one publication, researchers attempted to assess the effectiveness of information on the principles of proper nutrition, especially the principles of the Mediterranean diet, provided by the attending physicians. The target group was 78 patients aged 40-82, treated in Warsaw cardiology clinics. It was shown that these patients did not have sufficient knowledge on the principles of nutrition. However, most of them were willing to receive additional information. Only $12.0 \%$ of patients received a recommendation to implement a Mediterranean diet from a doctor. The same percentage (12.0\%) was encouraged to take advantage of the dietary advice [22].

Public knowledge on the prevention of cardiovascular diseases, as well as knowledge on the principles of the Mediterranean diet, as well as the benefits of its use can reduce the incidence of cardiovascular and nervous system diseases.

\section{CONCLUSIONS}

Inhabitants of the Silesian Province have a sufficient level of knowledge about the preventive use of the Mediterranean diet. Respondents as the benefits of using the Mediterranean diet more often indicated a reduction in the risk of cardiovascular disease than in the prevention of nervous system diseases.

Public knowledge on the prevention of cardiovascular diseases, as well as knowledge on the principles of the Mediterranean diet, as well as the benefits of its use, can reduce the incidence of cardiovascular and nervous system diseases.

\section{REFERENCES}

1. Magierski R, Antczak-Domagała K, Sobów T. Dieta jako czynnik protekcyjny otępienia. Aktual Neurol. 2014;14(3):167-174. doi: 10.15557/AN.2014.0019.

2. Dochniak M, Ekiert K. Żywienie w prewencji i leczeniu choroby Alzheimera i choroby Parkinsona. Piel. Zdr. Publ. 2015;5 (2):199-208.

3. Chudzińska M, Wołowiec $k$, Zukow W, Sinkiewicz W. Dieta śródziemnomorska zalecana nie tylko w chorobach sercowo naczyniowych. Journal of Education, Health and Sport. 2017; 7(6): 732-746. doi: http://dx.doi.org/10.5281/zenod0.999004.

4. Wyka J. Czynniki żywieniowe w zapobieganiu chorobie Alzheimera. Rocz Panstw Zakl Hig. 2012;63(2):135-140.

5. Casas R, Castro-Barquero S, Estruch R, Sacanella E. Nutrition and Cardiovascular Health. Int J Mol Sci. 2018;19 (12):3988. doi:10.3390/ ijms19123988.

6. Jaworski M. Łagodzenie objawów poznawczych poprzez stosowanie odpowiedniej diety u osób z chorobą Alzheimera. Neuropsychiatr Neuropsychol. 2010;5(3-4):141-148.

7. Paterson KE, Myint PK, Jennings A et al. Mediterranean Diet Reduces Risk of Incident Stroke in a Population With Varying Cardiovascular Disease Risk Profiles. Stroke. 2018; 49 (10): 2415-2420. doi:10.1161/ STROKEAHA.117.020258.

8. Gajewska D, Pałkowska-Goździk E, Lange E, et al. Standardy postępowania dietetycznego w kardiologii. Stanowisko Polskiego Towarzystwa Dietetyki 2016. 2016;9.

9. Gao M, Wang F, Shen Y, Zhu X, Zhang X, Sun X. Trajectories of Mediterranean Diet Adherence and Risk of Hypertension in China: Results from the CHNS Study, 1997-2011. Nutrients. 2018;10(12):2014. doi:10.3390/nu10122014.

10. Ferraro R, Pallazola V, Micho E. Physical activity, CVD, and older adults. AGING 2019;11 (9):2545-2546. doi: 10.18632/aging.101942.

11. Włodarek D, Głąbska D. Dieta a nadciśnienie tętnicze. Kardiol Dypl. 2016:15(1/2):46-52.

12. Dudkowiak R, Gryglas A, Poniewierka, E. The role of diet and antioxidants in the prevention of Alzheimer's disease. J Med Sci. 2016;85(3):205-212.

13. WHO. Global recommendations on physical activity for health. 2010.

14. Krzyżanowska E, Zwolan E, Łuczyk $R$, et al. Poziom wiedzy studentów Uniwersytetu Medycznego w Lublinie na temat czynników ryzyka choroby niedokrwiennej serca.J Edu Health Sport. 2017;7(7):453-478. doi: http://dx.doi.org/10.5281/zenodo.835017.

15. Markiewicz-Górka I, Korneluk J, Pirogowicz I. Aktywność fizyczna oraz wiedza studentów Akademii Medycznej we Wrocławiu na temat roli w profilaktyce chorób-badanie ankietowe. Fam Med. Primary Care Rev. 2011;13:436-439.

16. Rajewski P, Rajewski P, Dobosz K, Waleśkiewicz-Ogórek K. Wpływ zmiany stylu życia na wybrane parametry antropometryczne u otyłych kobiet. Fam Med Primary Care Rev. 2012;14 (3):420-423. 
17. Schlegel-Zawadzka M, Darłak M, Żwirska J. Porównanie sposobu żywienia wybranych grup dorosłych osób z Polski i Grecji w aspekcie diety śródziemnomorskiej. Badania własne. Bromat Chem Toksykol. 2010;43(4):453-460.

18. Cichocka A. Dieta śródziemnomorska w profilaktyce pierwotnej choroby niedokrwiennej. Endokrynol Otyłość 2005;1(3):30-39.

19. Dąbkowska M. Wpływ spożycia kwasów tłuszczowych trans tfa na rozwój zespołu metabolicznego. Acta Salut Sci 2019;1:41-51.

20. Gibała M, Janowski GJ. Znaczenie diety w prewencji oraz wyrównaniu nadciśnienia tętniczego. Chor Serca Naczyń 2016;13 (4):265-270.

21. Zych P, Szostak-Węgierek D. Ocena zgodności modelu żywienia studentów Warszawskiego Uniwersytetu Medycznego z zasadami diety śródziemnomorskiej. Nowa Med. 2013;3:107-110.

22. BłachewiczS, Cichocka A. Informacje na temat diety śródziemnomorskiej - przekazywane przez lekarzy pacjentom w wybranych warszawskich poradniach kardiologicznych częśćl. Gab Pryw. 2011;09-10(214):40-47.

\section{ORCID and contributionship}

Kamila Wachuła - 0000-0003-0330-4010 A,B,C,D

Joanna Furman - 0000-0002-9835-8240 D

Beata Łabuz-Roszak - 0000-0002-9835-8240 A,C,E,F

\section{Conflict of interest}

Authors declare no conflict of interest.

\author{
CORRESPONDING AUTHOR \\ Beata Łabuz-Roszak \\ Department of Basic Medical Sciences, \\ Faculty of Health Sciences in Bytom, \\ Medical University of Silesia \\ Piekarska Street 18, Bytom \\ tel. 605097110; \\ e-mail:broszak@sum.edu.pl
}

Received: 13.01 .2020

Accepted: 05.05 .2020

A - Work concept and design, B - Data collection and analysis, C - Responsibility for statistical analysis,

D-Writing the article, $\mathbf{E}$-Critical review, $\mathbf{F}$ - Final approval of the article 